Saudi Journal of Business and Management Studies Abbreviated Key Title: Saudi J Bus Manag Stud ISSN 2415-6663 (Print) |ISSN 2415-6671 (Online) Scholars Middle East Publishers, Dubai, United Arab Emirates Journal homepage: https://saudijournals.com/sibms

Original Research Article

\title{
The Influence of Motivation, Destination Image \& Destination Trust which had an Impact on Millennials' Visit Decision to The National Museum
}

\author{
Vidya Anggraeni ${ }^{1 *}$, Rina Astini ${ }^{2}$ \\ ${ }^{1}$ Student of Magister Management Program, Mercu Buana University, Jakarta, Indonesia \\ ${ }^{2}$ Lecturer of Magister Management Program, Mercu Buana University, Jakarta, Indonesia
}

DOI: $10.36348 / \mathrm{sjbms.2020.v05i10.001}$

| Received: 03.10.2020 | Accepted: 14.10.2020 | Published: 18.10.2020

*Corresponding author: Vidya Anggraeni

\section{Abstract}

These research aims to find out regarding the influence from motivation, destination image and destination trust on millennial's visit decision to the National Museum. Museums in Indonesia provided great potential for public education. However, there are still many people who consider museums as a place to keep historical items and a place to collect items which have high artistic value, especially the millennial generation (Y Generations). Most of millennials (Y Generations) were born during 1980-2000 which characters of this generation were always attached and usually like to travel somewhere. The number of samples in this research amounted to 155 people who were selected by Hair et al's theory. Data gathered method by distributing questionnaires based on a Likert scale which test for validity and reliability, then were analyzed using SEM-LISREL version 8.80. The results from this research was indicated that motivation, destination image, destination trust had significant impact on visit decision.

Keywords: Motivation, destination image, destination trust, visit decision.

Copyright (C) 2020 The Author(s): This is an open-access article distributed under the terms of the Creative Commons Attribution 4.0 International License (CC BY-NC 4.0) which permits unrestricted use, distribution, and reproduction in any medium for non-commercial use provided the original author and source are credited.

\section{INTRODUCTION}

Jakarta as the center of capital city is bustling with shopping centers and tourist attractions. One of the tourist attractions in Jakarta is the Museum. A museum can be categorized as a place for vacation, recreation and also as a learning medium for children, adults and families [1]. Visiting the museums will provides a different experience and chemistry compared to recreational places which exist of entertainment venues such as beaches or amusement parks. Museums usually keeps historical items and rare objects or collections from natural objects and archaeological artifacts.

According to data from DKI Jakarta Provincial Tourism and Culture Office which made on April 29, 2016, the total number of visits by domestic and foreign tourists in 2015 was 2,978,084 people. This data was taken from tourist visits at the Fine Arts Museum and Ceramics, Bahari Museum, Joang 45 Museum, National Museum, Jakarta History Museum, Textile Museum,
Wayang Museum, Sunda Kelapa Harbor, Archaeological Park, Onrust Island and National Monument.

Terms of millennial generation is a generation which born in 1980s to 2000s. The millennial generation tends to be more consumptive and also likes places which offered new atmosphere and experiences. They also like destinations that are instagramable or could be used to take pictures. According to a 2017 Boston Globe survey, $80 \%$ of Millennials made at least one trip in 2016 and usually more. These survey results showed that Millennials generation traveled on average 2.38 times in 2016, while the $\mathrm{X}$ generation (aged 40-51 years) had an average of 1.80 and baby boomers (aged 52-70 years) had an average of 1.65 . It could be said that on average Millennials travel $32 \%$ more often than Generation X and $44 \%$ more often than baby boomers. Strengthen this data, a survey from Expedia stated that 
Vidya Anggraeni \& Rina Astini., Saudi J Bus Manag Stud, October, 2020; 5(10): 506-511

$72 \%$ of Millennials preferred to vacation to a new place

than buying a car.

Table 1. The Data from Total Number of Visitors to the National Museum

\begin{tabular}{|c|c|c|c|c|c|c|c|c|c|c|c|c|c|}
\hline Year & Jan & Feb & Mar & Apr & Mei & June & July & Aug & Sep & Oct & Nov & Dec & Total \\
\hline 2017 & 25.521 & 27.647 & 33.851 & 30.205 & 18.315 & 1.048 & 20.887 & 26.526 & 23.970 & 30.823 & 32.057 & 31.108 & 315.654 \\
\hline 2018 & 24.930 & 24.233 & 30.809 & 29.497 & 14.651 & 228 & 21.585 & 21.013 & 30.873 & 30.973 & 39.139 & 32.996 & 318.091 \\
\hline
\end{tabular}

Source: Results of Interview with Head of Partnership \& Promotion of the National Museum

Based on data above, it can be seen that visitors to the national museum in 2017-2018 had increased. This could be momentum for researchers to used hyped this phenomenon by analyzing those prior research. The results from prior research was indicated that motivation had impact to the intention to visit a destination [2]. Furthermore, other research found that destination experience had influence on visit decision by tourist which had destination experiences [3]. According to Pitana and Diarta, the destination image will also impact to tourists in visiting a destination [4]. The results of previous research also explained that eWOM is positively related to goal belief and destination trust is positively related to visit decision [5]. In prior research it was found that destination trust had influence to the purpose of tourists' intention to visit [6]. Based on these pre-survey result to 35 respondents related to the factors that influence respondents on visit decision to the National Museum, it was found that as many as 35 respondents visited the National Museum to see firsthand the history of the past as well as gain insight (motivational factors), as many as 34 respondents visited this National Museum because they wanted the National Museum which famous by positive things such as exhibitions, entertainment or cultural attractions (destination image factor), and 34 respondents convinced that the National Museum had historical evidence (destination trust factor).

Based on these phenomena, previous research and pre-survey result above, the researcher was intend to carried out the research which related to "The Influence of Motivation, Destination Image \& Destination Trust which had an impact on Millenials' Visit Decision to the National Museum".

\section{LITERATURE REVIEW Motivation}

Motivation is an important factor for making trip decisions [7]. According to Josiam \& Frazier, Motivation of tourists to visit was influenced by several factors, such as: novelty seeking, stress, busting/fun, achievement and family oriented/education [8].

\section{Destination Image}

Destination image is the idea or concept that tourists have relate to product or service that purchased or going to buy [4]. Based on Echtner \& Brent Richie, destination image simply refers to the impression of a place or someone perception about certain area. Furthermore, they were explained that there are four components from destination image, which is: functional characteristic attributes, holistic functional characteristics, psychological characteristic attributes and psychological-holistic characteristics [9].

\section{Destination Trust}

Destination trust refers to visitor's willingness to rely on its ability to perform the advertised functions [5]. Gurviesz and Korchia defined that there are 3 (three) elements which shape this trust, such as: ability, integrity and benevolence [10].

\section{Visit Decision}

According to Jalilvand \& Samiei, these visit decision on tourists has similiar concept to consumer purchasing decisions which adapted into decisions to visit tourists [11]. Visit decision is a process where a visitor makes an evaluation and choosen one from an alternative based on certain considerations [11]. Adopting those theory from Kotler \& Armstrong regarding purchase decisions, So it could be concluded that to measured this visit decisions, the visitors need to consider these thing such as : destination selection, supplier selection, brand selection, visiting time and the number of visitors (crowded or not) from that destination [12].

\section{Theoretical Framework and Hypothesis}

These theoretical framework in this research which could be described as follows:

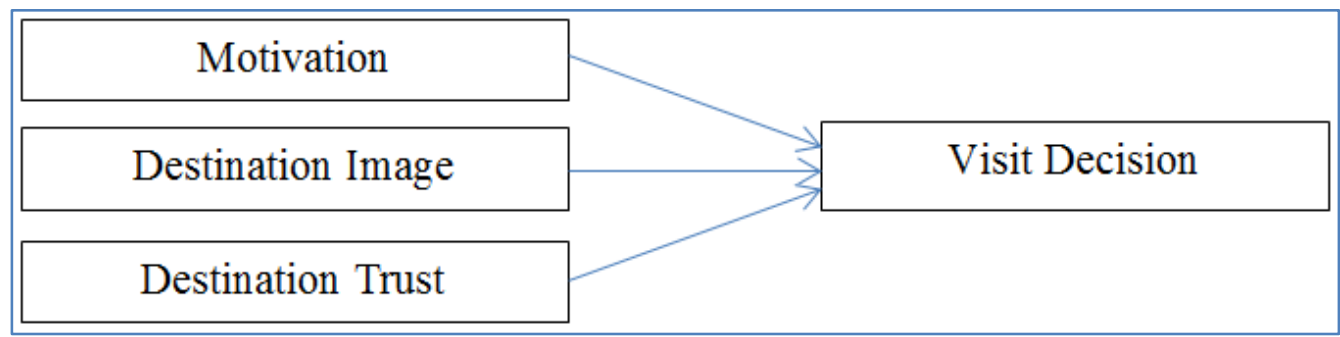

Fig-1: Theoretical Framework 
Based on these phenomena that occur and these theoretical framework and others theories served, the authors created these several hypothesis to be examined in this research, such as : Motivation had positive impact on millenials' visit decisions to the National Museum; Destination image had positive impact on millennials' visit decision to the National Museum; and destination trusts had positive impact on millennials' visit decision to the National Museum.

\section{RESEARCH METHODS}

The research design used in this research was a survey method. By questionnaires which distributed to respondents (millennials generation) who were visited the National Museum. Respondents in this research were millennials which aged (20-39 years). The independent variables in this research were Motivation, Destination Image, and Destination Trust. As for dependent variable was visit decision. These population were millennial visitors who have been and currently visiting the National Museum. To estimate the size of the sample, the writer adopted Hair's theory which took the $5 \times$ number of indicators [13], so this research basically used a sample of 155 respondents $(5 \times 31$ indicators) obtained Then it will be analyzed using
Structural Equation Model (SEM) with assist of LISREL 8.80 program to test those hypothesis.

\section{RESULTS AND DISCUSSION} Results

Based on these characteristics of 155 respondents, it could be seen that majority of respondents who included as millennials are women as many as 97 respondents $(63 \%)$ work as private employee $(49.03 \%$ or 76 respondents), and have a bachelor's degree $(72.90 \%$ or 113 respondents). Meaning that the majority of these millennials who makes a visit to the National Museum were female private employees who have broad knowledge/education and need an entertainment/tourism to unwind/and refresh their minds from daily work activities.

Based on these validity test result using LISREL, all statements from these research variables (motivation, destination image, destination trust, and visit decisions) have Standardize Loading Factor value $>0.5$, so it could be concluded that all statements were valid.

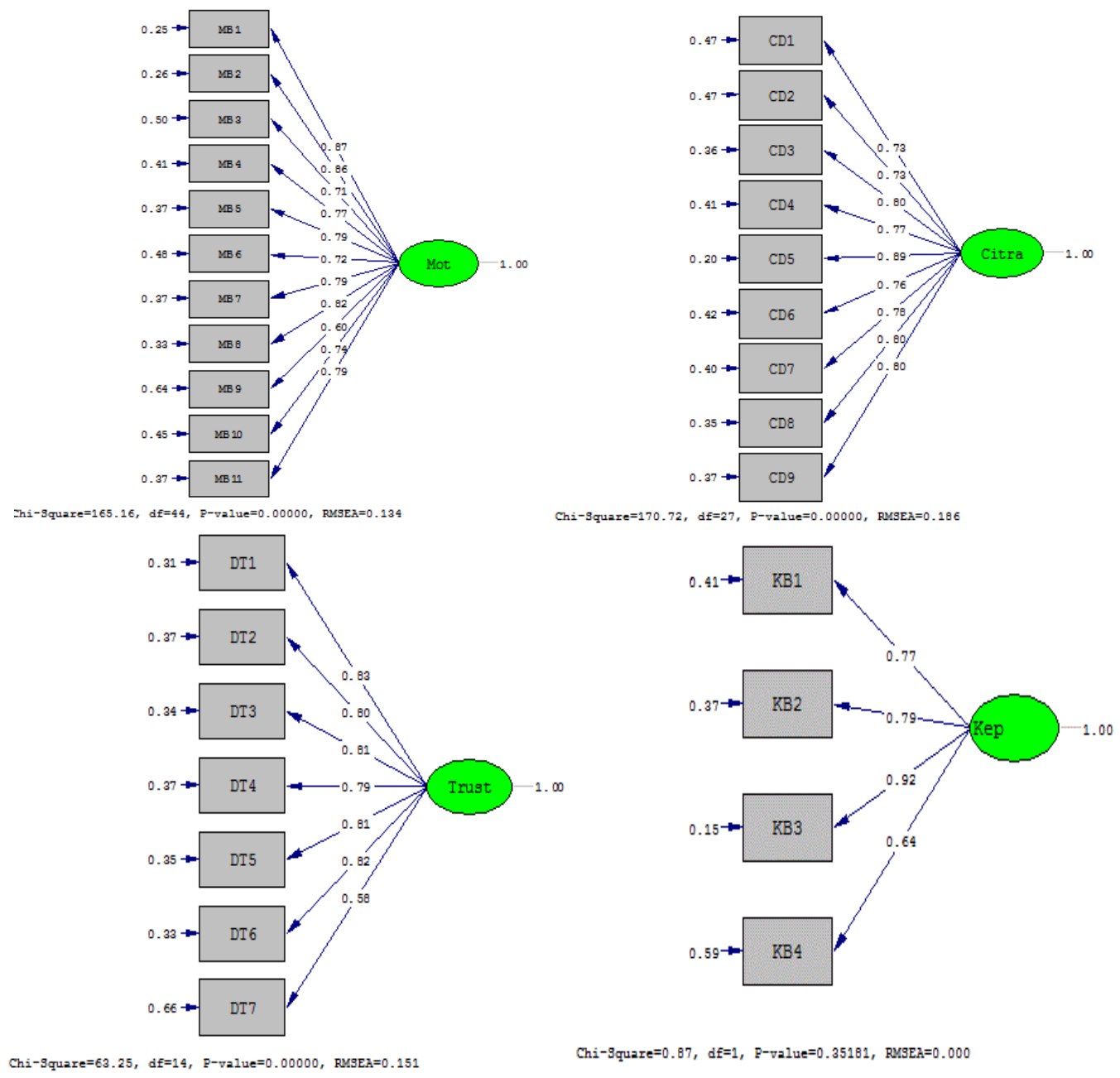

Fig-2: SEM's Measurement Test Result 
Table-2: Results of the Research Instrument Validity Test

\begin{tabular}{|l|l|l|l|}
\hline $\begin{array}{l}\text { Loading Factor } \\
\text { (Motivation) }\end{array}$ & $\begin{array}{l}\text { Loading Factor } \\
\text { (Destination Image) }\end{array}$ & $\begin{array}{l}\text { Loading Factor } \\
\text { (Destination Trust) }\end{array}$ & $\begin{array}{l}\text { Loading Factor } \\
\text { (Visit Decision) }\end{array}$ \\
\hline 0,87 & 0,73 & 0,83 & 0,77 \\
\hline 0,86 & 0,73 & 0,8 & 0,79 \\
\hline 0,71 & 0,8 & 0,81 & 0,92 \\
\hline 0,77 & 0,77 & 0,79 & 0,64 \\
\hline 0,79 & 0,89 & 0,81 & \\
\hline 0,72 & 0,76 & 0,82 & \\
\hline 0,79 & 0,78 & 0,58 & \\
\hline 0,82 & 0,8 & & \\
\hline 0,6 & 0,8 & & \\
\hline 0,74 & & & \\
\hline 0,79 & & & \\
\hline
\end{tabular}

Based on these reliability test result, motivation variable had CR value of 0.94 and VE value of 0.60 ; Destination image variable had CR value of 0.94 and VE value of 0.62 ; Destination trust variable had CR value of 0.92 , and $\mathrm{VE}$ value of 0.61 , visit decision variable had $C R$ value of 0.86 and $V E$ value of 0.62 . Based on these test results, it could be seen that all research variables had $\mathrm{CR}$ value $>0.6$ and $\mathrm{VE}$ value $>$ 0.5 , Meaning that all variables in this research were declared reliable.
After finding this overall model, this model then would be analyzed to see if it fits to the data. Based on these measurement suitability test result, it was obtained that Chi-Square $=970.69$, df $=416, \mathrm{P}$-Value $=0.000$, RMSEA $=0.091$ and AGFI 0.66. Thus, this model said not fit with the data, so it should be corrected or modified, with the aims to obtaining a model that really fits with sample dataset. After modification, these Normed Chi-Square $(\chi 2 / \mathrm{df})$ value becomes 1.321 (Fit), RMSEA becomes 0.046 (Fit) and AGFI becomes 0.78 (Marginal Fit), so it couod be said that the whole model could be said as a fit model with data.

Table-3: Result of Fit Test for Research Model Measurement Modification

\begin{tabular}{|l|l|l|l|l|}
\hline \multirow{2}{*}{ Goodnes of Fit Criteria } & \multicolumn{2}{|l|}{ Fit Size } & \multicolumn{2}{l|}{ Measurement Result } \\
\cline { 2 - 5 } & Good Fit & Marginal Fit & & \multicolumn{2}{|l|}{} \\
\hline$\chi^{2} /$ df & $<2.0$ & & 1.321 & Fit \\
\hline RMSEA & $<0.08$ & & 0.046 & Fit \\
\hline GFI & $\geq 0.90$ & $0.70<0.90$ & 0.81 & Marginal Fit \\
\hline AGFI & $\geq 0.90$ & $0.70<0.90$ & 0.78 & Marginal Fit \\
\hline NFI & $\geq 0.90$ & $0.80-<0.90$ & 0.97 & Fit \\
\hline NNFI & $\geq 0.90$ & $0.80-<0.90$ & 0.99 & Fit \\
\hline CFI & $\geq 0.90$ & $0.80-<0.90$ & 0.99 & Fit \\
\hline IFI & $\geq 0.90$ & $0.80-<0.90$ & 0.99 & Fit \\
\hline RFI & $\geq 0.90$ & $0.80-<0.90$ & 0.96 & Fit \\
\hline
\end{tabular}

The coefficient of determination $\left(\mathrm{R}^{2}\right)$ used to measure how good regression line matches to the actual line (Goodness of Fit). According to $\mathrm{R}^{2}$ test result, it was found that $98 \%$ from visit decision could explained by these independent variables (motivation, destination image and destination trust).

\section{Structural Equations \\ Kep $=0.22 * \mathrm{Mot}+0.33 *$ Citra $+0.56^{*}$ Trust, Errorvar $=0.016, \mathrm{R}^{2}=0.98$ \\ $\begin{array}{lll}(0.078) & (0.11) \quad(0.11) \quad(0.043)\end{array}$ \\ $\begin{array}{llll}2.78 & 3.05 & 5.14 & 0.37\end{array}$}

Fig-3: Structural Equation Model Output

Then, based on hypothesis test result, these following results were obtained as follows:

1) Those influence from motivation on visit decision had $\mathrm{t}$-Values $=2.78>1.96$, with positive coefficient value of 0.22 . Meaning that motivation had positive and significant impact on visit decisions (H1was accepted).

2) Those influence from destination image on visit decision had $\mathrm{t}$-value $=3.05>1.96$ with positive coefficient value of 0.33 . Meaning that destination 
image had positive and significant influence on visit decisions (H2 was accepted).

3) Those impact of destination trust on visit decision had $\mathrm{t}$-values $=5.14>1.96$, with positive coefficient value of 0.56 . Meaning that destination trust had positive and significant influence on visit decisions (H3 was accepted).

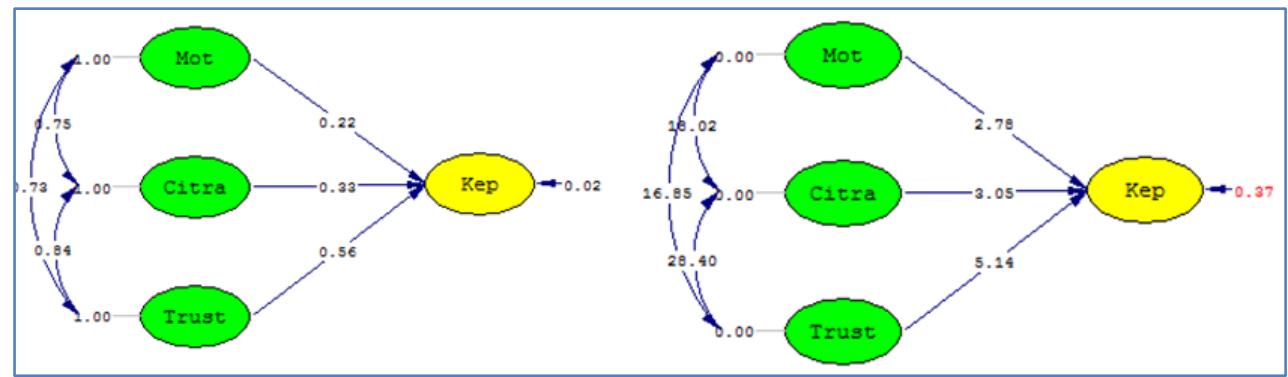

Fig-4: Path Diagram of Structural Model Estimates and t-Value

Table-4: Hypothesis Test Result

\begin{tabular}{|l|l|l|l|}
\hline Relationship Between Construct & Estimates & T-Values & Information \\
\hline Motivation -> Visit Decision & 0.22 & 3.78 & Positive Significant \\
\hline Destination Image -> Visit Decision & 0.33 & 3.05 & Positive Significant \\
\hline Destination Trust -> Visit Decision & 0.56 & 5.14 & Positive Significant \\
\hline
\end{tabular}

\section{DISCUSSION}

These hypothesis research $(\mathrm{H} 1)$ defined that motivation had positive and significant impact directly to visit decisions. Motivation is a potential power that exists within a human being, which could develop it or developed by a number of outside factors which essentially involved around monetary rewards and nonmonetary rewards. So, if the higher motivation to visit, the higher the level of visit decisions that generated by visitors who want to go tourism to what they wanted. These results were confirmed prior research which found that motivation influenced someone decision to visit tourist attractions $[2,14]$. Based on these empirical facts and supported by previous research results, it could be concluded that the first hypothesis could be accepted.

These hypothesis research (H2) stated that destination image had positive and significant impact directly to visit decision. Destination image is defined as a complex perception of a consumer or visitor on the attributes that noticeable from the tourist destination [15]. Brand image which built from this brand association is usually related to information which memorized by something related to the service/product/place related [12]. A destination image with good quality will provide an increasing in consumer visiting decision. In other words, if destination image increase, it will impact to the increase on visit decisions. These results were confirmed the results from prior research which found that destination image had positive impact towards visit decision [3, 16]. Based on these empirical facts and supported by the results from prior research it can be concluded that second hypothesis was accepted.
These hypothesis research $(\mathrm{H} 3)$ described that destination trust had positive and significant impact which directly to visit decisions. Destination trust refers to visitor's willingness to rely on ability of the destination to perform the advertised functions [5]. Destination trust is a sense of trust which arises in each tourist regarding a destination, which will create selfconfidence and pride in identifying themselves with the intended destination. Destination trust is variable which has the greatest influence on visit decisions, meaning the high consumer confidence in tourism spot will greatly determine by decision to visit tourists. These results were in line to previous research which found that destination trusts greatly influence by visit decision $[5,14]$. Based on these empirical facts and was supported by previous research results, it can be concluded that third hypothesis was accepted.

\section{CONCLUSION AND SUGGESTION Conclusion}

Based on these description and discussion from prior chapter, There has several conclusions were obtained from this research, such as : 1) Motivation variable had positive and significant impact on visit decisions; 2) Destination image variable had positive and significant impact on visit decisions; and (3) destination trust variable had positive and significant impact on visit decisions, destination trust variable is the variable which obtained highest influenced on visit decision.

\section{Suggestion}

Based on these results from several discussion analyses and some of conclusions above, the suggestions that recommend as a complements from these research results are:

1) The national museum needs to improve its 
promotional strategy by adding the trend of discussions which currently hyped among millennials so the visitors could be re-motivated to visit the national museum.

2) National museums need to give lots of concern to its service and communication in each museum officer in providing information or directions so the visitors would feel happy and comfortable when visiting.

3) High influence from destination trust on visit decision to the National Museum is something that needs to be considered by museum managers in increasing tourist visits. Destination Trust that consist from the dimensions of ability, integrity and benevolence which can be used as a reference in increasing tourist trust also will directly increase to this visit decision by tourists. National museums should pay attention to the needs of each visitor, especially on this millennials who has a high level of curiousity about various things and tends to be more critical, including about what they want and what their decided.

4) The researchers were expected for further research to explore more depth regarding these variables which have an influence on visit decisions. This high influence from destination trust on visit decisions which found in this research has open up any possibility of other influences from other variables, such as perceived price and destination experience. Second order data processing can be used to measure the dimensions of destination trust.

\section{REFERENCES}

1. Soedijati, E.K. (2014). The impacts of marketing mix on students' choice of university. Journal of Global Management, 7(1), 8.

2. Wu, Chih-Wen. (2015). Foreign tourists' intentions in visiting leisure farms. Journal of Business Research, 68, 757-762.

3. Mohsin, A., Lengler, J., \& Chaya, P. (2017). Does travel interest mediate between motives and intention to travel? A case of young Asian travellers. Journal of Hospitality and Tourism Management, 31, 36-44.

4. Pitana, I. G. (2009). Pengantar Ilmu Pariwisata. Yogyakarta: Andi.

5. Abubakar, A. M. (2016). Impact of Online WOM on Destination Trust and Intention to Travel: A Medical Tourism Perspective. Journal of Destination Marketing and Management, 5(3), 192-201.
6. Su, L., Liana, Q., \& Huang, Y. (2020). How do tourists' attribution of destination social responsibility motives impact trust and intention to visit? The moderating role of destination reputation. Tourism Management, 77, 103970.

7. Isa, S.M., \& Ramli, L. (2014). Factors influencing tourist visitation in marine tourism: lessons learned from FRI Aquarium Penang, Malaysia. International Journal of Culture, Tourism and Hospitality Research, 8(1), 103-117.

8. Deksono, F. R. (2017). Pengaruh Motivasi Wisata dan Electronic Word Of Mouth Terhadap Minat Berkunjung ke Daya Tarik Goa Pindul. Skripsi. Program Studi Manajemen. Fakultas Ekonomi. Universitas Sanata Dharma. Yagyakarta.

9. Astini, R., \& Sulistiyowati, I. (2015). Pengaruh Destination Image,Travel Motivaiton dan Kualitas Pelayanan Terhadap Kepuasan Pengunjung (Studi Kasus pada Wisatawan Nusantara Muslim di Pantai Carita Pandeglang Banten). Jurnal Ilmiah Manajemen dan Bisnis, 1(3).

10. Gurviesz, P., \& Korchia, M. (2003). Test of a Consumer-Brand Relationship Model Including Trust and Three Consequences. 30th International Research Seminar in Marketing, La Londe les Maures, France.

11. Fitri, A., Kumadji, A., \& Kusumawati, A. (2015). Pengaruh Word of Mouth Terhadap Minat Berkunjung serta Dampaknya pada Keputusan Berkunjung (Survei pada Pengunjung Tempat Wisata "Jawa Timur Park 2" Kota Batu). Jurnal Administrasi Bisnis, 24(1), 1-6.

12. Kotler, P., \& Armstrong, G. (2016). Marketing Management, (Vol. 15th). Edition New Jersey: Pearson Pretice Hall, Inc.

13. Hair, J.F., Jr. Black, W.C., Babin, B.J., \& Anderson. (2010). Multivariate Data Analysis. ( $7^{\text {th }}$ ed). New Jersey: Prentice Hall.

14. Nugraha, A.K.N.A. (2014). Consumer's decision to visit to a risky destination country:An anakysis of tourist's risk taking. Thesis. Department of Marketing and Management, Faculty of Business and Economics, Macquarie University.

15. Zhang, H., Xu, F., Leung, H.H., \& Cai, L.A. (2014). The Influence of Destination-Country Image on Prospective Tourists' Visit Intention: Testing Three Competing Models. Asia Pacific Journal of Tourism Research.

16. Alvarez, M. D., Campo, S. (2019). Consumer Animosity and its influence on visiting decision of US Citizens. Current Issue in Tourism, 1-15. 